\title{
A Diversity Index Model based on Spatial Analysis to Estimate High Conservation Value in a Mining Area
}

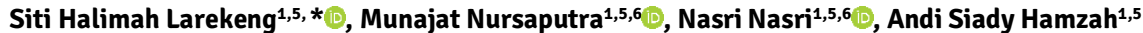 \\ (ㄷ, Andi Subhan Mustari ${ }^{2}$, Abdur Rahman Arif ${ }^{-0}$, Aris Prio Ambodo ${ }^{4}$, Yohan Lawang ${ }^{4}$, Andri \\ Ardiansyah $^{4}$
}

\section{AFILIATIONS \\ 1. Faculty of Forestry, Universitas Hasanuddin, Makassar, Indonesia \\ 2. Faculty of Engineering, Universitas Hasanuddin, Gowa, Indonesia \\ 3. Faculty of Mathematics and Natural Sciences, Universitas Hasanuddin, Makassar, Indonesia \\ 4. Vale Indonesia, East Luwu, Indonesia \\ 5. Biodiversity Research Group (BRG), Faculty of Forestry, Universitas Hasanuddin, Makassar, Indonesia \\ 6. Forest and Society Research Group (FSRG), Faculty of Forestry, Universitas Hasanuddin, Makassar, Indonesia \\ Correspondence: \\ sittihalimah@unhas.ac.id}

\section{RECEIVED 2021-02-17} ACCEPTED 2022-01-15

COPYRIGHT @ 2022 by Forest and Society. This work is licensed under a Creative Commons Attribution 4.0 International License

\begin{abstract}
Large scale land-based investments have a significant impact on natural resources and environmental conditions. It is necessary to protect areas of high conservation value ( $\mathrm{HCV}$ ) within land management investments, such as the mining sector, to minimise this impact. The existence of high conservation value sites in locations with activities related to the mining sector is intended to maintain the ecological and conservation value of a mining investment area. We demonstrate a model that can identify potential high conservation value sites in mining areas using remote sensing data and spatial analysis compiled with field observation data. The research was conducted in one of the largest nickel mining areas (71,047 ha) in South Sulawesi, Indonesia. We mapped vegetation density using the normalized difference vegetation index (NDVI), calculated from Sentinel-2 imagery. We also collected biodiversity data in predetermined inventory sampling plots, which we then used to estimate species richness using the Shannon-Wiener diversity index. Using a linear regression model to compare the normalized difference vegetation index value in each sampling plot with the biodiversity value of flora and fauna, we then estimated biodiversity distribution patterns for the entire study area. We found that potential high conservation value areas (areas likely to have high biodiversity based on our regression model) covered 40,000 ha, more than half of the total concession area.
\end{abstract}

\section{KEYWORDS}

Diversity Index; GIS Modelling; HCV; Mining Area; South Sulawesi

\section{INTRODUCTION}

The mining sector plays an important role in Indonesia's economic development. The mining sector contributed around $9.01 \%$ of the national gross domestic product in 2018, up from 6.55\% in 2017 (Central Bureau of Statistics, 2020), creating jobs in rural areas, accelerating economic development and improving regional infrastructure (Hidayat et al., 2014; Suciyanti et al., 2018). The Government of Indonesia has increasingly supported land-based investments to boost the economy and create jobs with the issuance of Law No. 11/ca. 2020 regarding Job Creation, better known as the Omnibus Law (Indonesian Government, 2020).

The new law simplifies permit granting, which will likely bring new investment in land-based sectors such as forestry, plantation, and mining (Samosir, 2019). However, an increase in large-scale land-based investments, such as investments in the mining sector, will probably have significant negative impacts on ecosystems (Ardhana, 2010; Ardhana, 2015; Mahalik, 2016; de Castro Pena et al., 2017; Sahide et al., 2018; Sonter et al., 2018; Sahide et al. 2020). This is due to the forest clearing and conversion of natural landscapes, eliminating or reducing biodiversity (Salman et al., 2018; Fisher et al., 2020). 
To address these concerns and assess the most strategic sites for mining, The Ministry of Environment and Forestry obligates companies that utilize forest areas to apply sustainable management principles to improve environmental management. Its implementation is monitored through the Program for Environmental Performance Rating (PROPER), developed by the Ministry of Environment and Forestry (Ministry of Environment and Forestry 2018). This program aims to encourage companies to improve their environmental management. Based on this assessment, the company will get appreciation according to the level of environmental management.

One of the requirements of good environmental management for companies holding forest utilization permits is to protect areas with high biodiversity and contain endemic and endangered species (Voge \& Hütz-Adams, 2014; Hoi \& Dung, 2021). Areas with high biodiversity must first be identified through a High Conservation Value (HCV) determination process. In Indonesia, this has been formalized through the Regulation of the Director of Natural Resources Conservation (No. 5/2017) regarding Guidelines for Determination of Areas with High Conservation Value, wherein this regulation describes the procedure and importance of determining potential areas that have the potential to become an ecological corridor (Ministry of Environment and Forestry, 2017a).

Currently, the implementation of HCV in Indonesia has been done primarily by oil palm plantation companies. Mining companies are still looking for ways to implement $\mathrm{HCV}$ assessments and management plans. The existence of regulations requiring the protection of $\mathrm{HCV}$ areas will make this a necessity in the future, potentially becoming more important than the Environmental Impact Assessment (AMDAL). In theory, several $\mathrm{HCV}$ evaluation indicators, including environmental and social protection, are also present in the AMDAL study. AMDAL is essentially a method for acquiring a permit to utilize the region ('go' or 'no go'). Meanwhile, the existence of this HCV is expected to protect the land not only at the start of the management process but also during the mining phase. HCVs are used to identify areas that must be protected, and requires management and monitoring of mining activity in the surrounding areas.

According to Tropenbos Indonesia (2019), implementing HCV in the mining sector still necessitates transforming HCV management strategies into standard operational procedures that can be applied at the mining management unit level, therefore techniques for identifying HCV in mining areas must be developed. Given these limits, technology that reduces the human resources required for environmental management by mining companies, which must frequently check the state of biodiversity across wide areas, would be beneficial.

PT Vale Indonesia Tbk is one of the mining companies attempting to identify and manage HCV areas in its concession (PTVI). PTVI, formerly known as PT. Inco, is a nickel mining company that has been in operation since 1968. This mining company is the largest nickel mining company in South Sulawesi and is located between three ancient lakes, the deepest lakes in Southeast Asia, i.e., Lake Matano, Lake Mahalona and Lake Towuti, which have been designated as conservation areas by the Indonesian government because of the unique biodiversity and high endemism.

Management of HCV areas can be carried out sustainably if supported by adequate data. The required data include biodiversity, landscape, environmental services, basic needs of the community, and social/cultural value (Konsorsium Revisi $\mathrm{HCV}$ Toolkit Indonesia, 2008). Biodiversity in HCV areas is a fundamental aspect that needs to be studied (Ahlunnisa et al., 2016; Heriyanto et al., 2019). This includes the 
need to identify those areas with high biodiversity of flora and fauna. This research is a collaborative project related to monitoring surveys and biodiversity conservation strategies in the PTVI concession area. This research aims to provide baseline data on biodiversity in mining areas for PROPER requirements. It was conducted to identify areas with high conservation value based on biodiversity by utilizing remote sensing technology and geographic information systems. This approach is expected to provide an easy-to-implement solution for mining companies to determine $\mathrm{HCV}$ in their concession areas.

\section{MATERIALS AND METHODS}

\subsection{Study Location}

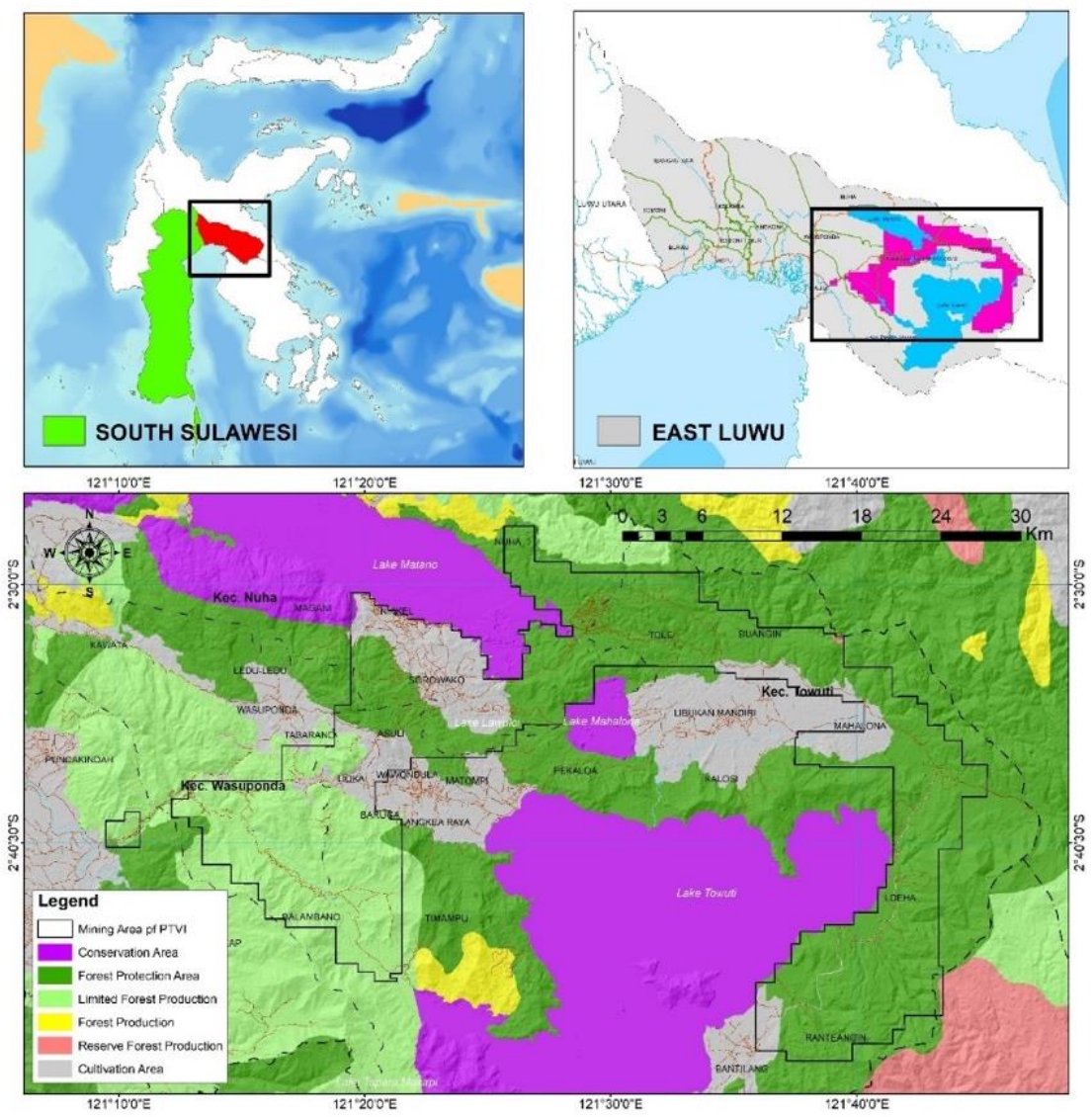

Figure 1. Map of the study area

This research was carried out in the PTVI mining area in Sorowako, East Luwu Regency, South Sulawesi, Indonesia (Figure 1). The company has a concession area of 71,047 hectares, which contains over 20 village administrative areas. The majority (58.70\%) of PTVI's permit area is on land zoned as protected forests. The remaining area is located in limited production forest areas (24.22\%), conservation areas (0.67\%), and 
non-forest areas (16.42\%) (Ministry of Environment and Forestry 2019). The mining area is also surrounded by several conservation areas, namely natural tourism parks Lake Mahalona, Lake Matano, and Lake Towuti.

\subsection{Satellite Data and Processing}

We used the normalized difference vegetation index (NDVI) to identify areas of vegetation cover and estimate vegetation density in the PTVI concession area. We then used vegetation density estimates to estimate the distribution of biodiversity. We calculated NDVI using Sentinel-2 (S2) satellite imagery. S2 imagery has high accuracy in vegetation analysis and provides a better response in monitoring vegetation globally than Landsat imagery (Lima et al., 2019; Modica et al., 2019; Sidiq, 2021). S2 multispectral imagery has a high spatial and temporal resolution.

To calculate NDVI values within the concession area, we processed three S2 image scenes collected between September and November 2019. The selection of sensing time was solely based on cloud-free image availability. We conducted radiometric correction for reflectance at the sensor and top of atmosphere correction using the QGIS Semi-Automatic Classification tool. The corrected images were used to calculate NDVI values to identify vegetated areas. NDVI was calculated using the following formula (eq. 1) (Lillesand et al., 2005):

$$
\text { NDVI }=(\rho \text { nir }- \text { ored }) /(\rho \text { nir }+\rho \text { red })
$$

Where,

pnir : reflectance value of NIR band

pred : reflectance value of RED band

The NDVI can be used to describe the condition of land cover based on its type (vegetation vs. non-vegetation) and density (vegetation vs. non-vegetation) (Bochenek et al., 2018; Hoagland et al., 2018; Liang et al., 2018; Rahmat et al., 2018). The vegetation index threshold value is determined to characterize the land cover in the PTVI mining area. The NDVI index ranges from -1 (no vegetation) to 1 (vegetation). According to several studies, an NDVI index value of less than 0.3 indicates sparse vegetation, whereas a value greater than 0.6 indicates dense vegetation (Dasuka et al., 2016; Zaitunah et al., 2018; Solihin \& Putri, 2021). The index values used in this analysis ranged from 0.5 to 0.6 for non-vegetation cover, 0.5 to 0.6 for shrubs, 0.6 to 0.65 for low density forests, 0.65 to 0.7 for medium density forests, and $>0.7$ for high density forests (Vision of Technology, 2009). A visual check is performed on the merged image to ensure that the class division results accurately describe general field conditions. The band combination used is 12 (SWIR) - 8A (Vegetation Red Edge) - 4 Red). Vegetation areas are depicted in green, while open areas are depicted in brown (Miranda et al., 2018; Szostak et al., 2018).

\subsection{Biodiversity Survey Analysis}

We used a stratified purposive sampling method (Kangas \& Maltamo, 2006). Strata were defined based on the vegetation class in the mining area, specifically forests and shrubs. These classes are believed to be a habitat for flora and fauna species found in the PTVI mining area, where forests consist of density classes, and shrubs are included as observation areas because shrubs are a transitional area (ecotone) between vegetation and the non-vegetation regions. This field survey was carried out at the end of 2019 and early 2020 with the distribution of the plot as presented in Figure 2. 


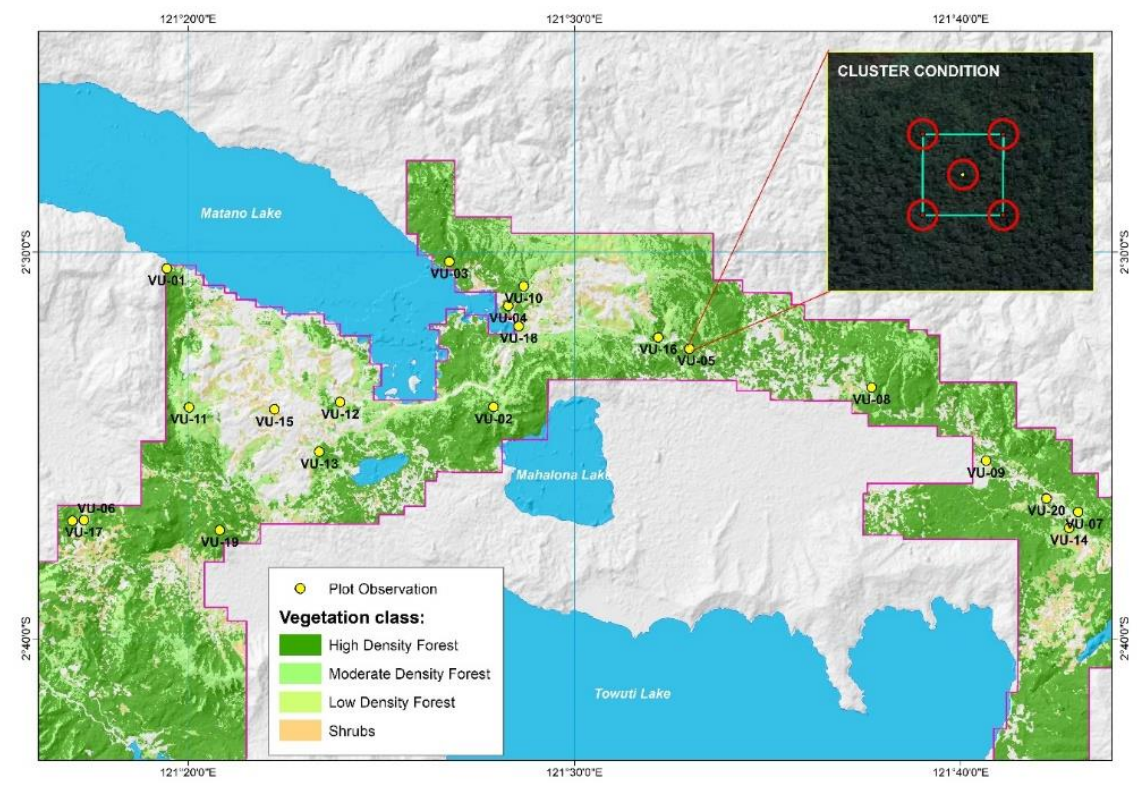

Figure 2. Distribution of Observation Cluster in the PTVI Mining Area

We selected square clusters with $100 \mathrm{~m} \times 100 \mathrm{~m}$ as observation sites in each vegetation class. We placed five circular plots at each corner of the cluster and in the middle of the cluster with each plot area 0.1 ha (radius $=17.8 \mathrm{~m}$ ) so that the area of one cluster is 0.5 ha (Ministry of Environment and Forestry, 2017b). We selected 20 clusters, each containing five plots. However, based on field conditions, only 19 clusters could be visited, with the remaining cluster (VU-3) being inaccessible due to the safety and health restrictions of the mining company. From the 19 clusters, there were 95 observation plots.

Observation plots were located in the forest and shrubland cover classes, with forest divided into three sub-classes: high-density forest, moderate-density forest, and low-density forest. These classes were defined based on an analysis of NDVI. In each observation plot, the flora and fauna species found were identified using observation tally sheets. The species were then matched with an observation manual book in the field to identify them. Data obtained from the field were then analyzed to quantify the level of biodiversity using the Shannon-Wiener index. The formula (eq. 2) used for the Shannon-Wiener index is (Magurran, 2004; Jørgensen, 2010).

$$
H^{\prime}=-\sum\left(\frac{n i}{N}\right) \ln \left(\frac{n i}{N}\right)
$$

Where,

$\mathrm{H}^{\prime} \quad$ : Shannon-Wiener Diversity Index

ni : Total of individuals for the species-i

$\mathrm{N} \quad$ : Total of individual for all the species 


\subsection{Diversity Index Model}

We used a linear regression model (eq. 3) to identify areas likely to have high biodiversity to create a diversity index.

$$
Y^{\prime}=b_{0}+b_{1} X
$$

Where,

$Y$ : Diversity index value

$X$ : NDVI value

$b_{0}$ : constant value

$b_{1}$ : regression coefficient

To measure the model's validity, we performed a normality test on the parameters of the model builder. The validated model was then used to create a spatial map of diversity (Table 1). Spatial patterns of biodiversity distribution were analyzed based on diversity index value classes (Lee et al., 1978; Pertiwi et al., 2019).

Table 1. Classification of Diversity Index Value

\begin{tabular}{cc}
\hline Value Range & Diversity Type \\
\hline$H^{\prime}<1$ & Very Low \\
$1 \leq H^{\prime}<1.5$ & Low \\
$1.5 \leq H^{\prime}<2$ & Moderate \\
$2 \leq H^{\prime}<3$ & High \\
$H^{\prime} \geq 3$ & Very High \\
\hline
\end{tabular}

\section{RESULTS}

\subsection{Landcover Condition and Vegetation Density Index}

The NDVI land cover analysis found that forest is the dominant land cover in the mining area (high-density forest, medium density forest, low density forest and forest reclamation), covering $75.24 \%$ of the total mining concession area. This was followed by dryland agriculture (8.16\%). The distribution of land cover in the PTVI mining area in 2019 is presented in Table 2.

Table 2. Land Cover in the PTVI Mining Area

\begin{tabular}{clrr}
\hline \multirow{2}{*}{ No } & \multicolumn{1}{c}{ Land Cover } & \multicolumn{2}{c}{ Area } \\
\cline { 3 - 4 } & Hagh Density Forest & \multicolumn{1}{c}{$(\%)$} \\
\hline 1 & Hign & 38,579 & $54.30 \%$ \\
2 & Moderate Density Forest & 11,365 & $16.00 \%$ \\
3 & Dryland agriculture & 5,800 & $8.16 \%$ \\
4 & Mine occupation & 4,326 & $6.09 \%$ \\
5 & Shrubs & 3,791 & $5.34 \%$ \\
6 & Low Density Forest & 2,541 & $3.58 \%$ \\
7 & Bare land & 1,259 & $1.77 \%$ \\
8 & Lake & 1,194 & $1.68 \%$ \\
9 & Forest Reclamation & 972 & $1.37 \%$ \\
10 & Road & 285 & $0.40 \%$ \\
11 & Settlement & 251 & $0.35 \%$ \\
12 & River & 193 & $0.27 \%$ \\
13 & Rice field & 184 & $0.26 \%$ \\
14 & Water pool & 132 & $0.19 \%$ \\
15 & Mine Industry & 126 & $0.18 \%$ \\
16 & Airport & 22 & $0.03 \%$ \\
17 & Swamp & 22 & $0.03 \%$
\end{tabular}

Larekeng et al. (2022) 


\begin{tabular}{|c|c|c|c|}
\hline \multirow{2}{*}{ No } & \multirow{2}{*}{ Land Cover } & \multicolumn{2}{|c|}{ Area } \\
\hline & & (Ha) & (\%) \\
\hline 18 & DAM & 5 & $0.01 \%$ \\
\hline & Total & 71,047 & $100.00 \%$ \\
\hline
\end{tabular}

\subsection{Biodiversity Index}

To determine the level of biodiversity in the study area, we calculated the biodiversity index for the types of flora and fauna found in the observed land cover types. There are four types of land cover observed in the field: high-density forest, medium density forest, low-density forest, and shrubs. The results of observations in each cluster included data on flora identification at the tree and pole levels and data on fauna identification at the Aves, Mammals, Reptiles, and Amphibians levels. Table 3 shows the results of the biodiversity index calculation for flora and fauna at each land cover.

Table 3. Diversity Value of Flora and Fauna based on the Shannon-Wiener Index

\begin{tabular}{|c|c|c|c|c|c|c|c|}
\hline \multirow[b]{2}{*}{ Landcover } & \multirow[b]{2}{*}{ Cluster } & \multicolumn{3}{|c|}{ Flora } & \multicolumn{3}{|c|}{ Fauna } \\
\hline & & $\begin{array}{l}\text { Total of } \\
\text { Species }\end{array}$ & $\begin{array}{c}\text { Total of } \\
\text { Individual }\end{array}$ & $\mathrm{H}^{\prime}$ & $\begin{array}{l}\text { Total of } \\
\text { Species }\end{array}$ & $\begin{array}{c}\text { Total of } \\
\text { Individual }\end{array}$ & $\mathrm{H}^{\prime}$ \\
\hline \multirow{8}{*}{$\begin{array}{l}\text { High- } \\
\text { Density } \\
\text { Forest }\end{array}$} & VU-01 & 32 & 330 & 2.81 & 11 & 46 & 2.08 \\
\hline & VU-02 & 33 & 535 & 2.84 & 11 & 15 & 2.34 \\
\hline & VU-05 & 29 & 461 & 2.95 & 19 & 57 & 2.64 \\
\hline & VU-06 & 26 & 333 & 2.83 & 18 & 71 & 2.45 \\
\hline & VU-07 & 33 & 522 & 2.91 & 11 & 22 & 2.24 \\
\hline & VU-08 & 24 & 508 & 2.97 & 11 & 16 & 2.34 \\
\hline & VU-16 & 32 & 471 & 3 & 11 & 23 & 2.25 \\
\hline & & 30 & 451 & 2.89 & 13 & 36 & 2.33 \\
\hline \multirow{5}{*}{$\begin{array}{l}\text { Moderate } \\
\text { Density } \\
\text { Forest }\end{array}$} & VU-10 & 32 & 401 & 2.79 & 25 & 52 & 2.76 \\
\hline & VU-11 & 23 & 613 & 2.58 & 17 & 27 & 2.57 \\
\hline & VU-13 & 27 & 507 & 2.93 & 12 & 43 & 1.89 \\
\hline & VU-12 & 13 & 320 & 1.89 & 10 & 26 & 1.85 \\
\hline & & 24 & 460 & 2.55 & 16 & 37 & 2.27 \\
\hline \multirow{5}{*}{$\begin{array}{l}\text { Low- } \\
\text { Density } \\
\text { Forest }\end{array}$} & VU-04 & 22 & 483 & 2.46 & 19 & 28 & 2.85 \\
\hline & VU-09 & 32 & 286 & 2.43 & 21 & 45 & 2.74 \\
\hline & VU-14 & 17 & 368 & 2.23 & 10 & 12 & 2.25 \\
\hline & VU-15 & 21 & 430 & 2.4 & 13 & 90 & 1.83 \\
\hline & & 23 & 392 & 2.38 & 15.75 & 43.75 & 2.42 \\
\hline \multirow{5}{*}{ Shrubs } & VU-17 & 12 & 234 & 1.72 & 15 & 99 & 1.7 \\
\hline & VU-18 & 7 & 244 & 1.88 & 3 & 4 & 1.04 \\
\hline & VU-19 & 13 & 74 & 2.1 & 12 & 17 & 2.36 \\
\hline & VU-20 & 0 & 0 & 0 & 3 & 13 & 0.86 \\
\hline & & 8 & 138 & 1.43 & 8 & 33 & 1.49 \\
\hline
\end{tabular}

Note: Numbers in bold represent the average value of each landcover type.

From the calculation of the Shannon-Wiener index as presented in Table 3, when the average biodiversity index for each land cover is analyzed, it can be seen that high density forest has the greatest biodiversity index value for flora, followed by medium density forest, low density forest, and shrubs. Low density forest, high density forest, medium density forest, and shrubs were all confirmed to have fauna. The amount and varieties of flora and fauna encountered at each land cover define the value of the biodiversity index.

The Wallacea area's priority species, including flora and fauna, occupy most of the PTVI concession area. At the tree level, 11 different types of flora are priority species in 
the Wallacea area and are categorized as endemic species. Agathis dammara, Diospyros celebica, Garcinia celebica, Kjelbergiodendron celebicum, Lithocarpus celebicus, Weinmannia devogelii, Dillenia serrata, Pterospermum celebicum, Sarcotheca celebica, Pterocarpus indicus, Pterocarpus indicus, and Pterocarpus indicus are among the 12 endemic species. Pterocarpus indicus, one of the 11 indigenous species, is listed as an endangered species on the 2020 IUCN RED LIST.

There are 19 species of priority fauna with endemic status from all categories found in the PTVI concession area, including 16 species of aves/birds and 3 species of mammals. The Minister of Environment and Forestry's Regulation No. P. 106/MENLHK/SETJEN/KUM.1/12/2018 protects a total of 15 species, including 12 species of aves/birds and 3 species of mammals. Haliastur indus, Accipiter nanus, Accipiter gularis, Ictinaetus malayensis, Falco moluccensis, Accipiter trinotatus, Spilornis rufipectus, Pandion haliaetus, Rhyticeros cassidix, Rhabdotorrhinus exarhatus, Loriculus stigmatus, and Macrocephalon maleo are the 12 aves/birds species Meanwhile, the 3 protected mammal species are the digo monkey (Macaca ochreata), Timor deer (Rusa timorensis), and Anoa (Bubalus depressicornis).

\subsection{The Estimation of Diversity Index Model}

The results of the biodiversity index acquired in the observation cluster were then linked to the study area's NDVI value to produce a map showing the distribution of biodiversity, including flora and fauna. The NDVI value for each land cover is linked to each biodiversity index value. So that the relation between the biodiversity index value and the NDVI value can be determined afterwards. The regression model for each land cover, provided in Tables 4 and 5, explains this relation.

Table 4. The Estimator Model for Flora Diversity Distribution in PTVI

\begin{tabular}{lcccc}
\hline \multicolumn{1}{c}{ Landcover } & Regression Model & $\begin{array}{c}\text { Correlation } \\
\text { Value }\end{array}$ & $\begin{array}{c}\text { Determination } \\
\text { Value }\end{array}$ & $\begin{array}{c}\text { Significance } \\
\text { Value }\end{array}$ \\
\hline $\begin{array}{l}\text { High-Density } \\
\begin{array}{l}\text { Forest } \\
\text { Moderate Density }\end{array}\end{array}$ & $\mathrm{y}=-1.4119 \mathrm{x}+3.9121$ & 0.85 & 0.72 & 0.02 \\
$\begin{array}{l}\text { Forest } \\
\text { Low-Density }\end{array}$ & $\mathrm{y}=0.0105 \mathrm{x}+0.7138$ & 0.33 & 0.11 & 0.67 \\
$\begin{array}{l}\text { Forest } \\
\text { Shrubs }\end{array}$ & $\mathrm{y}=0.0145 \mathrm{x}+0.5076$ & 0.53 & 0.02 & 0.86 \\
\hline
\end{tabular}

Table 5. The Estimator Model for Fauna Diversity Distribution in PTVI

\begin{tabular}{lcccc}
\hline \multicolumn{1}{c}{ Landcover } & Regression Model & $\begin{array}{c}\text { Correlation } \\
\text { Value }\end{array}$ & $\begin{array}{c}\text { Determination } \\
\text { Value }\end{array}$ & $\begin{array}{c}\text { Significance } \\
\text { Value }\end{array}$ \\
\hline $\begin{array}{l}\text { High-Density } \\
\begin{array}{l}\text { Forest } \\
\text { Moderate Density }\end{array}\end{array}$ & $\mathrm{y}=-0.6828 \mathrm{x}+2.823$ & 0.17 & 0.03 & 0.71 \\
$\begin{array}{l}\text { Forest } \\
\text { Low-Density }\end{array}$ & $\mathrm{y}=0.0148 \mathrm{x}+0.7206$ & 0.47 & 0.22 & 0.53 \\
$\begin{array}{l}\text { Forest } \\
\text { Shrubs }\end{array}$ & $\mathrm{y}=0.0286 \mathrm{x}+0.4857$ & 0.93 & 0.87 & 0.07 \\
\hline
\end{tabular}

Tables 4 and 5 show the estimated distribution of flora and fauna models based on the results of a simple regression analysis of the biodiversity index value vs. the NDVI value. Each land cover; high density forest, medium density forest, low density forest, and shrubs; analyzed for their biodiversity in the field and the value of regression analysis was applied. The high coefficient of determination demonstrates a strong 
relationship between land cover type and the biodiversity index (R2). According to Sarwono (2006), the analyzed variables show a strong relationship if the R2 value is in the range of $>0.5-0.75$.

The high coefficient of determination for flora is found in the high-density forest cover type. In contrast, the low coefficient of determination for fauna is found in the low-density forest cover type, according to the results analysis. The value of the biodiversity index in each land cover has a significant impact on the relation between NDVI and biodiversity index. For flora, a strong relationship between NDVI and a high biodiversity index was discovered in high-density forests because there are so many varieties of flora in high-density forests than in other land covers. As for fauna, these are more commonly found in low density forests. This is because fauna, like aves, use low density forests for roaming and foraging, and is easily spotted in these land cover typesh.

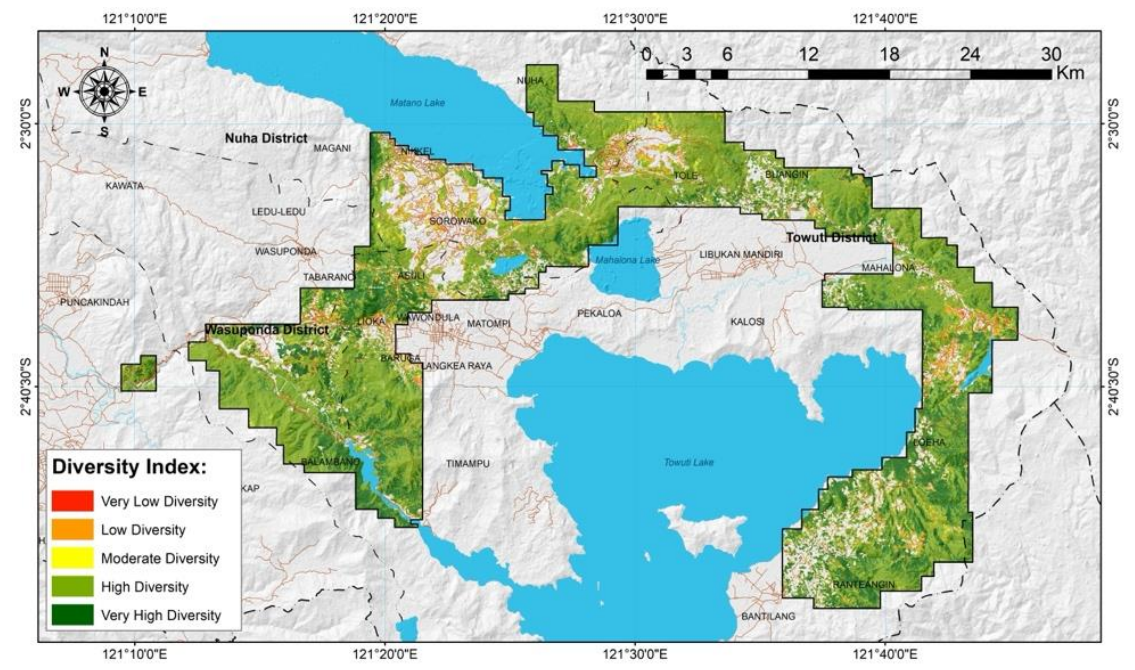

Figure 3. Map of diversity index model distribution for flora in PTVI mining area

The estimator model that has been tested was then used to map the diversity index model by assigning a biodiversity value to each pixel based on the NDVI raster data. That specific NDVI values were given specific biodiversity values. The classification of diversity levels using the Shannon-Wiener biodiversity classification is presented in Figure 3 and 4, and more detail the area distribution for each class is showed by Table 6.

Table 6. Distribution of diversity levels at PTVI mining area

\begin{tabular}{lrrrr}
\hline \multirow{2}{*}{ Type of Diversity } & \multicolumn{2}{c}{ Flora } & \multicolumn{2}{c}{ Fauna } \\
\cline { 2 - 5 } & \multicolumn{1}{c}{$(\mathrm{Ha})$} & \multicolumn{1}{c}{$(\%)$} & \multicolumn{1}{c}{$(\mathrm{Ha})$} & \multicolumn{1}{c}{$(\%)$} \\
\hline Very Low & 872.58 & $1.20 \%$ & $1,195.15$ & $1.68 \%$ \\
Low & $1,593.55$ & $2.20 \%$ & $2,183.76$ & $3.07 \%$ \\
Moderate & $2,464.86$ & $3.50 \%$ & $4,945.60$ & $6.96 \%$ \\
High & $37,711.82$ & $53.10 \%$ & $48,015.08$ & $67.58 \%$ \\
Very High & $14,574.52$ & $20.50 \%$ & 874.61 & $1.23 \%$ \\
\hline
\end{tabular}

Diversity index values in the study area ranged from 0.4 to 4.2 for flora and 0.4 to 
3.6 for fauna. Based on the study area's index value, areas with an index value of $\mathrm{H}>2$ are areas with a high and very high diversity index. This high value of flora and fauna diversity is then combined to determine the overall area of high biodiversity in the PTVI concession area. Areas that have a high level of biodiversity can be considered as high conservation value areas. These are presented in Figure 5.

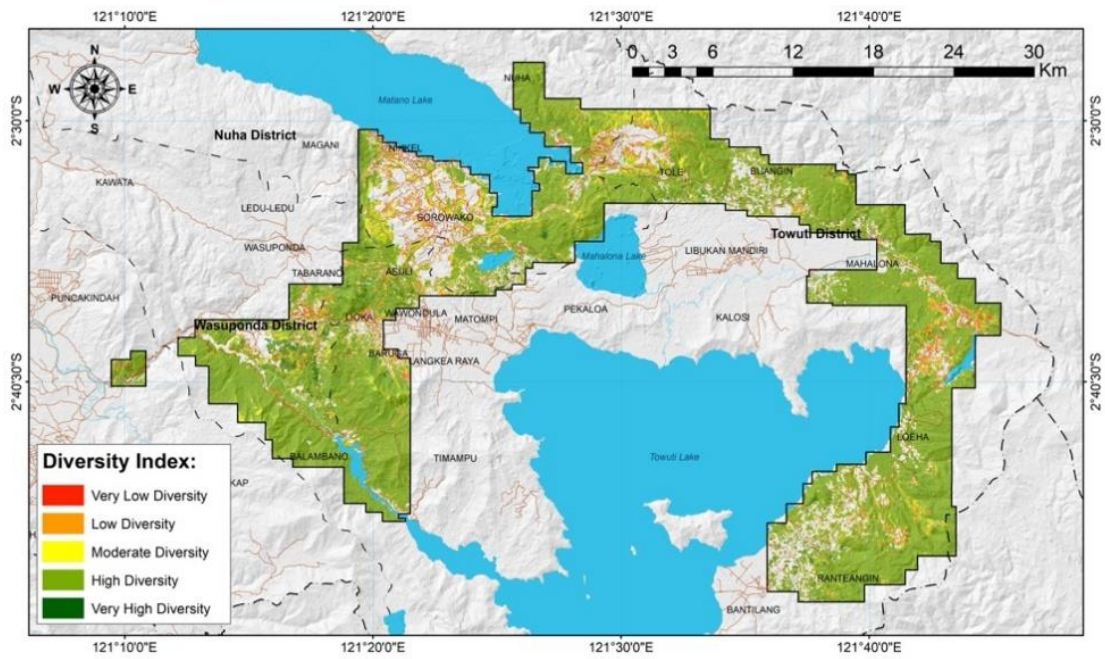

Figure 4. Map of diversity index model distribution for fauna in PTVI mining area

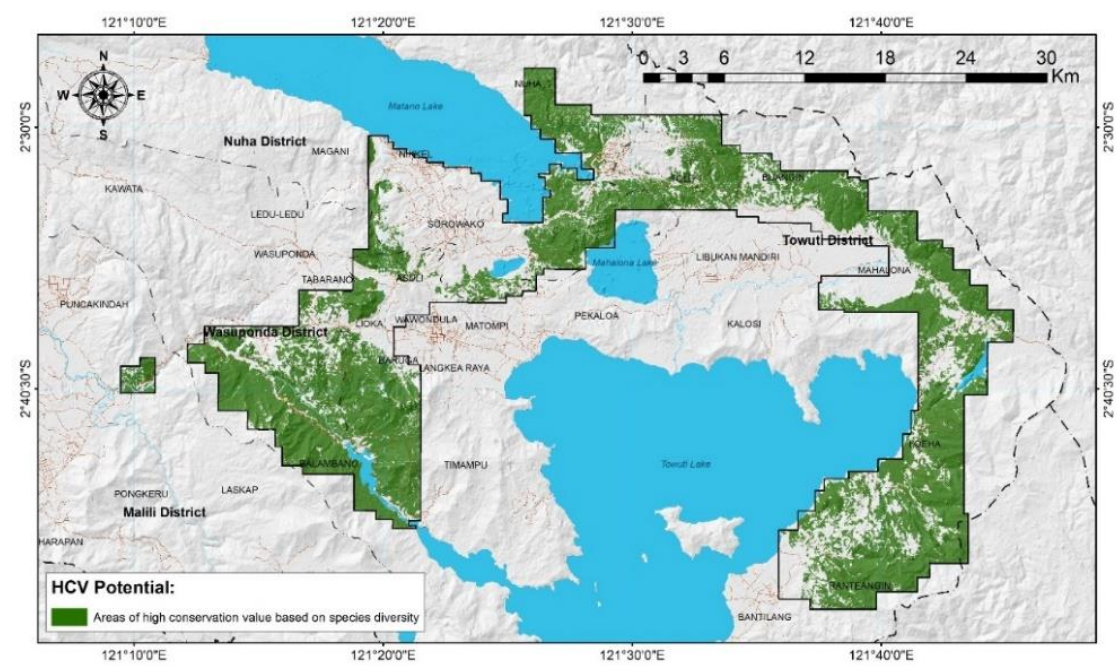

Figure 5. Map of HCV based on model diversity index in PTVI Mining Area 


\section{DISCUSSION}

$\mathrm{HCV}$ assessments in mining areas may require a lot of time, cost, and effort if they must be carried out manually in the field. However, using a remote sensing and geographic information systems approach, the location of HCV areas can be estimated using a distribution map of the diversity index model. The areas identified as having a high biodiversity index have the potential to be designated as HCV. This is important, as mining companies operating in Indonesia in the future will need to prepare mining plans that consider strategic forms of land management which minimize disturbance to the HCV areas.

From the data on the distribution of the diversity index in the PTVI area, those areas which will be designated as HCV areas can be identified. HCV area determination from the biodiversity aspect is based on vegetation types with high biodiversity index values. Forest cover in the study area based on the interpretation of S2 was relatively high. This illustrates that the company has not cleared much of the area that has been permitted also because of the success of the mine reclamation activities carried out after clearance for mining operations.

The high forested area in the PTVI mining area can indicate high biodiversity in the region. Based on observations of several clusters, it is known that the biodiversity index values of both flora and fauna in the study area are quite variable. Different habitat conditions can cause this difference in biodiversity index values. This habitat variability affects the number of species found in the observation clusters. The highest average numbers of species are found in the high-density forest, medium density forest, low-density forest, forest reclamation areas, and the lowest average numbers are in shrub cover type, for both flora and fauna. This illustrates that the better the condition of the forest, the higher the level of biodiversity in faunal and floral species. Areas with a high diversity index value need to be considered for HCV designation.

Several aspects are assessed in the HCV assessment, including biodiversity, social and cultural values, and environmental services. However, the function of an HCV assessment is to identify an area that has the potential to be designated for protected status. HCV assessment in mining areas may require a lot of time, cost, and effort if it has to be done manually in the field. However, using a remote sensing approach and GIS, the HCV area can be estimated using the distribution map of the biodiversity index. Although not all aspects such as social and cultural aspects can be assessed with this approach, at least this model can provide quick information to mining companies regarding how much area must be protected in their concession areas. From this assessment, the PTVI mining area that should be designated as HCV based on the biodiversity aspect amounts to $40,881.59$ ha or $57.5 \%$ out of the total PTVI concession area, shown in Figure 5. The determination of this HCV area can be used as a reference or indicator to assess the sustainable natural resources and environment management in mining areas. In the future, to prepare mining plans, the companies need to consider the strategic forms of land management that minimize disturbance to HCVs.

\section{CONCLUSION}

The study results demonstrated that remote sensing technology can be used to estimate high conservation value areas. The vegetation index can be combined with biodiversity data from several observation plots to calculate the biodiversity index for the entire study area. The results of this modeling indicate areas with a high index 
category for flora and fauna habitat. These areas have the potential to be designated as areas of high conservation value. For example, it is known that nearly half of the PTVI mining area has the potential to be designated as an area of high conservation value. Indeed, not all aspects of HCV determination, such as social and cultural factors, can be obtained from remote sensing data. However, this analysis can serve as the basis for considering an area that needs to be protected from a biodiversity perspective, and the modelling results are also fairly accurate. In the future, this approach will undoubtedly aid mining companies in environmental management, as this analysis can be performed using freely available images with a high spectral and temporal resolution, allowing for periodic monitoring of the area's condition without requiring significant demand for human resources.

Author Contributions: Conceptualization, S.H.L., M.N., N. and A.S.H.; Methodology, S.H.L., M.N., N., and A.S.H.; Software, M.N.; Validation, S.H.L., M.N., N., and A.S.H.; Formal Analysis, S.H.L., A.S.M., A.P.A., Y.L., and A.A.; Investigation, S.H.L., M.N., N., A.S.H. and A.R.A; Resources, S.H.L., and A.S.M.; Data Curation, M.N.; Writing-Original Draft Preparation, M.N.; Writing-Review \& Editing, S.H.L., M.N., N., and A.S.H.; Visualization, M.N.; Supervision, S.H.L., A.S.M., A.P.A., Y.L. and A.A.; Project Administration, S.H.L., A.S.M., A.P.A., Y.L. and A.A.; Funding Acquisition, S.H.L., A.S.M., A.P.A., Y.L., and A.A.

Conflicts of Interest: The authors declare that they have no known competing financial interests or personal relationships that could have appeared to influence the work reported in this paper.

Acknowledgments: This research was supported by Universitas Hasanuddin and PT. Vale Indonesia Tbk., we would like to thank Jennifer Hacking (WWF-Congo) for their sincere help in proof-reading our manuscript and we are also thanked M. Yusuf Hidayatullah, Abd. Rosadi, Muhammad Sigit, Andi Utami Batara Putri, A. Aulia Iswari Syam'un, Jumriah Lira, Siti Islamiyah Anggoro, Bismiragandi Ahmad, Maria Imaculata Beren and Sri Wahyuni Jufri for their support as the analysis assistant and surveyor who supported the completion of this research.

\section{REFERENCES}

Ahlunnisa H.A.N, Zuhud E.A.M, \& Yanto D.A.N. (2016). Keanekaragaman Spesies Tumbuhan Di Areal Nilai Konservasi Tinggi (NKT) Perkebunan Kelapa Sawit Provinsi Riau. Media Konservasi, 21(1), 91-98. https://doi.org/10.29244/medkon.21.1.91-98

Ardhana, I. P. G. (2010). Konservasi Keanekaragaman Hayati pada Kegiatan Pertambangan di Kawasan Hutan di Indonesia. Jurnal Ilmu Pertanian Indonesia, 15(2), 71-77.

Ardhana, I. P. G. (2015). Kajian Kerusakan Sumberdaya Hutan Akibat Kegiatan Pertambangan. Ecotrophic: Journal of Environmental Science, 6(2), 87-93.

Bochenek Z, Ziolkowski D, Bartold M, Orlowska K, Ochtyra A. (2018). Monitoring forest biodiversity and the impact of climate on forest environment using highresolution satellite images. European Journal of Remote Sensing, 51(1), 166-181. https://doi.org/10.1080/22797254.2017.1414573

de Castro Pena, J. C., Goulart, F., Fernandes, G. W., Hoffmann, D., Leite, F. S., dos Santos, N. B., ... \& Rodrigues, M. (2017). Impacts of mining activities on the potential geographic distribution of eastern Brazil mountaintop endemic species. Perspectives in Ecology and Conservation, 15(3), 172-178. http://dx.doi.org/10.1016/j.pecon.2017.07.005

Central Bureau of Statistics. 2020. [Seri 2010] Laju Pertumbuhan Kumulatif Produk 
Domestik Bruto Menurut Lapangan Usaha (Persen), 2014-2016. Badan Pusat Statistik. Retrieved from https://www.bps.go.id/dynamictable/2016/02/ 09/1138/-seri-2010-laju-pertumbuhan-kumulatif-produk-domestik-brutomenurut-lapangan-usaha-persen-2014-2016.html

Dasuka, Y. P., Sasmito, B., \& Haniah, H. (2016). Analisis Sebaran Jenis Vegetasi Hutan Alami Menggunakan Sistem Penginderaan Jauh (Studi Kasus: Jalur Pendakian Wekas Dan Selo). Jurnal Geodesi Undip, 5(2), 1-8.

Fisher, M. R., Verheijen, B., \& Sahide, M. A. K. (2020). Community and conservation in Wallacea: Making the case for the region, a methodological framework, and research trends. Forest and Society, 4(1), 1-19. https://doi.org/10.24259/fs.v4i1.9569

Heriyanto, N. M., Samsoedin, I., \& Bismark, M. (2019). Keanekaragaman Hayati Flora dan Fauna di Kawasan Hutan Bukit Datuk Dumai Provinsi Riau (Biodiversity Flora and Fauna in the Region Forest Bukit Datuk Dumai Riau Province). Jurnal Sylva Lestari, 7(1), 82-94. https://doi.org/10.23960/jsl1782-94

Hidayat, W., Rustiadi, E., \& Kartodihardjo, H. (2014). Dampak Sektor Pertambangan terhadap Perekonomian Wilayah di Kabupaten Luwu Timur. Jurnal Economia, 10(1), 65-80.

Hoagland, S. J., Beier, P., \& Lee, D. (2018). Using MODIS NDVI phenoclasses and phenoclusters to characterize wildlife habitat: Mexican spotted owl as a case study. Forest Ecology and Management, 412, 80-93. http://dx.doi.org/10.1016/j.foreco. 2017.12.017

Hoi, N. D., \& Dung, N. T. (2021). Seasonal Dynamics of Tropical Forest Vegetation in Ngoc Linh Nature Reserve, Vietnam Based on UAV Data. Forest and Society, 5(2), 376-389. https://doi.org/10.24259/fs.v5i2.13027

Indonesian Government. (2020). Law No. 11 of 2020 on Job Creation. Indonesia.

Jørgensen, S. E., Xu, F. L., Marques, J. C., \& Salas, F. (2010). Application of Indicators for the Assessment of Ecosystem Health. In Jørgensen, S. E., Xu, F. L., \& Costanza, R. (Eds.), Handbook of Ecological Indicators for Assessment of Ecosystem Health (2 $2^{\text {nd }}$ Edition) (pp. 9-76). CRC Press.

Kangas, A., \& Maltamo, M. (Eds.). (2006). Forest Inventory: Methodology and Applications. Springer.

Konsorsium Revisi HCV Toolkit Indonesia. (2008). Panduan Identifikasi Kawasan Bernilai Konservasi Tinggi di Indonesia. Tropenbos International Indonesia Programme.

Lee, C. D., Wang, S. B., \& Kuo, C. L. (1978). Benthic Macroinvertebrate and Fish as Biological Indicators of Water Quality, With Reference of Community Diversity Index. International Conference on Water Pollution Control in Development Countries.

Liang, L., Chen, F., Shi, L., \& Niu, S. (2018). NDVI-derived forest area change and its driving factors in China. PloS one, 13(10), e0205885. https://doi.org/10.1371/journal.pone.0205885

Lillesand, T., Kiefer, R. W., \& Chipman, J. (2015). Remote Sensing and Image Interpretation. John Wiley \& Sons.

Lima, T. A., Beuchle, R., Langner, A., Grecchi, R. C., Griess, V. C., \& Achard, F. (2019). Comparing Sentinel-2 MSI and Landsat $8 \mathrm{OLI}$ imagery for monitoring selective logging in the Brazilian Amazon. Remote Sensing, 11(8), 961. https://doi.org/10.3390/rs11080961 
Magurran, A. E. (2004). Measuring Biological Diversity. Blackwell Publishing.

Mahalik, G., \& Satapathy, K. B. (2016). Environmental impacts of mining on biodiversity of Angul-Talcher open mining site, Odisha, India. Scholars Academic Journal of Biosciences, 4(3A), 224-227.

Ministry of Environment and Forestry. (2017a). Pedoman Penentuan Areal Bernilai Konservasi Tinggi. Ministry of Environment and Forestry.

Ministry of Environment and Forestry. (2017b). Petunjuk Teknis Inventarisasi Hutan Pada Kesatuan Pengelolaan Hutan Lindung (KPHL) dan Kesatuan Pengelolaan Hutan Produksi (KPHP) (P.1/PKTL/IPSDH/PLA.1/1/2017). Ministry of Environment and Forestry.

Ministry of Environment and Forestry. (2018). Program Penilaian Peringkat Kinerja Perusahaan dalam Pengelolaan Lingkunga. Ministry of Environment and Forestry. Retrieved from https://www.menlhk. go.id/site/post/119

Ministry of Environment and Forestry. (2019). Regulation of Ministry of Environment and Forestry No. 362 Tahun 2019 about Changes in the Forest Area of South Sulawesi Province. Ministry of Environment and Forestry.

Miranda, E., Mutiara, A. B., \& Wibowo, W. C. (2018). Classification of land cover from Sentinel-2 imagery using supervised classification technique (preliminary study). Proceedings of 2018 International Conference on Information Management and Technology, 69-74. Institute of Electrical and Electronics Engineers Inc (IEEE). https://doi.org/10.1109/ICIMTech.2018.8528122

Modica G., Pollino M., Solano F. (2019) Sentinel-2 Imagery for Mapping Cork Oak (Quercus suber L.) Distribution in Calabria (Italy): Capabilities and Quantitative Estimation. In Calabrò F., Della Spina L., Bevilacqua C. (Eds.), New Metropolitan Perspectives. ISHT 2018. Smart Innovation, Systems and Technologies, Vol. 100 (pp. 60-67). Springer. https://doi.org/10.1007/978-3-319-92099-3_8.

Pertiwi, N., Taufieq, N. A. S., \& Hiola, S. F. (2019). The Diversity of Riparian Trees Vegetation at Around The Lawo River, South Sulawesi, Indonesia. Journal of Physics: Conference Series, 1244(1), 012008). IOP Publishing. http://dx.doi.org/10.1088/1742-6596/1244/1/012008

Rahmat, A., Abi Hamid, M., Zaki, M. K., \& Mutolib, A. (2018). Normalized Difference Vegetation Index in the Integration of Conservation Education. Indonesian Journal of Science and Technology, 3(1), 47-52. https://doi.org/10.17509/ijost.v3i1.10798

Salman, D., Yusran, Y., \& Sahide, M. A. K. (2018). Integrated analysis of forest policies and their impacts on landscape and lifescape dynamics: A case study in the walanae forest management unit, indonesia. Journal of Landscape Ecology, 11(3), 155-174. http://dx.doi.org/10.2478/jlecol-2018-0017

Samosir, H. (2019). Problematic Policy: Environmental Impacts of Traditional Mining in Papua. Hasanuddin Law Review, 5(3), 321-329. http://dx.doi.org/10.20956/halrev.v5i3.2219

Sahide, M. A. K., Fisher, M., Nasri, N., Dharmiasih, W., Verheijen, B., \& Maryudi, A. (2020). Anticipating a new conservation bureaucracy? Land and power in Indonesia's Essential Ecosystem Area policy. Land Use Policy, 97, 104789. https://doi.org/10.1016/j.landusepol.2020.104789

Sahide, M. A. K., Fisher, M. R., Maryudi, A., Dhiaulhaq, A., Wulandari, C., Kim, Y. S., \& Giessen, L. (2018). Deadlock opportunism in contesting conservation areas in Indonesia. Land Use Policy, 77, 412-424. https://doi.org/10.1016/j.landusepol. 


\subsubsection{0}

Sarwono, J. (2006). Metode Penelitian Kuantitatif dan Kualitatif. Graha Ilmu.

Sidiq, A. (2021). Critical Approaches to GIS and Spatial Mapping in Indonesia Forest Management and Conservation. Forest and Society, 5(2), 190-195. https://doi.org/10.24259/fs.v5i2.10921

Solihin, M. A., \& Putri, N. (2020). Keragaman penggunaan lahan eksisting di hulu Sub DAS Cikapundung berdasarkan indeks vegetasi dan temperatur permukaan lahan. Agrikultura, 31(3), 251-262. https://doi.org/10.24198/agrikultura. v31i3.29467

Sonter, L. J., Ali, S. H., \& Watson, J. E. (2018). Mining and biodiversity: key issues and research needs in conservation science. Proceedings of the Royal Society $B$, 285(1892), 20181926. https://doi.org/10.1098/rspb.2018.1926

Suciyanti, M., Suseno, T., \& Saleh, R. (2018). Analisis Dampak Kegiatan Pertambangan Tembaga terhadap Perekonomian Provinsi Papua. Jurnal Teknologi Mineral Dan Batubara, 14(1), 75-92. https://doi.org/10.30556/jtmb.Vol14.No1.2018.394

Szostak, M., Hawryło, P., \& Piela, D. (2018). Using of Sentinel-2 images for automation of the forest succession detection. European Journal of Remote Sensing, 51(1), 142-149. https://doi.org/10.1080/22797254.2017.1412272

Tropenbos Indonesia. (2019). Mainstreaming HCV in the Mining sector: Need to emphasise developing practical guidelines on HCV management, monitoring and reporting. Tropenbos Indonesia. Retrieved from https://www.tropenbosindonesia.org/news/mainstreaming+hcv+in+the+mining+sector:++need+to+em phasis+on+developing+practical+guidelines+on+hcv+management,+monitoring tand+reporting

Vision of Technology. (2009). Indicator: NDVI - Vegetation health \& density. Vision of Technology. Retrieved from http://endeleo.vgt.vito.be/dataproducts.html\#ndvi

Voge A-K, Hütz-Adams F. (2014). Sustainable Palm Oil: Aspiration or Reality? The potential and limitations of the Roundtable on Sustainable Palm Oil (RSPO). Palm Oil Study 44. Bread for the World - Protestant Development Service Protestant Agency for Diaconia and Development.

Zaitunah, A., Samsuri, S., Ahmad, A. G., \& Safitri, R. A. (2018). Normalized difference vegetation index (ndvi) analysis for land cover types using landsat 8 oli in besitang watershed, Indonesia. IOP Conference Series: Earth and Environmental Science, 126(1), 012112. IOP Publishing. http://dx.doi.org/10.1088/1755$1315 / 126 / 1 / 012112$ 